\title{
Supply response of indian maize farmers - A conceptual analysis
}

\author{
A. Angelin Keerthiga*, S. Murali Gopal and P. Asha Priyanka \\ Department of Agricultural Economics, Tamil Nadu Agricultural University, Coimbatore (T.N.) India \\ (Email: keerthikailamathy95@gmail.com)
}

\begin{abstract}
Maize is the third most important cereal and it is cultivated throughout the year. Maize consumption is growing at a compound annual growth rate (CAGR) of 11 per cent in last 5 years. To meet the growing demand, maize production must grow at 15 per cent CAGR, while the current CAGR is only 4 per cent. Consequently, import of maize to India has increased exponentially. Hence, there is a need to increase the production in India in order to reduce the increasing imports and to meet the domestic demand. There are various factors that influence the crop output. This study proposes to identify the factors influencing maize acreage in India by appraising significant six supply response functions in order to strategize policies for improvement of maize production. Koyck second order lag model which incorporated two year lag of area under the crop, one year lagged price of the own crop and competitive crop (groundnut) and minimum support price in the current sowing season was found to be the well suited model to analyze the supply response of Indian maize farmers. The study suggests the government to promote market information among the farmers and to procure the produce from the farmers based on minimum support price.
\end{abstract}

Key Words : Supply response, Area response, Nerlovian model

View Point Article : Keerthiga, A. Angelin, Gopal, S. Murali and Priyanka, P. Asha (2019). Supply response of indian maize farmers - A conceptual analysis. Internat.J.agric.Sci., 15 (2) : 275-282, DOI:10.15740/HAS/IJAS/15.2/275-282.Copyright@ 2019: Hind Agri-Horticultural Society.

Article History : Received : 24.01.2019; Revised : 10.05.2019; Accepted : 18.05.2019

*Author for correspondence: 